\title{
Antimicrobial activity, physical-chemical and activity antioxidant of honey samples of Apis mellifera from different regions of Paraná, Southern Brazil
}

\author{
Angelívia GREGÓRIOํ, Douglas GALHARDO², Maria Josiane SEREIA³, Priscila WIELEWSKI², \\ Lilian GAVAZZONI ${ }^{1}$, Idineia Fernande dos SANTOS ${ }^{3}$, Gleyce Stefani Santos Gaspar Monteiro Gomes SANGALETI ${ }^{3}$, \\ Erica Cavalheiro CARDOSO ${ }^{3}$, Tatiane Layanne BORTOTI ${ }^{3}$, Leticia Aguiar ZANATTA ${ }^{3}$, \\ Lucas Machado GONÇALVES ${ }^{3}$, Mônica Araujo SUZIN³ , Ariane Ambrósio SANTOS 3 , \\ Vagner de Alencar Arnaut de TOLEDO ${ }^{2 *}$ ๔
}

\begin{abstract}
Antimicrobial activity of honey has lately drawn researchers' attention, especially due to the fact that its antimicrobial capacity has been proven. The aim of this study was analyzing bactericidal and bacteriostatic action in the pathogenic microorganisms Staphylococcus aureus, Escherichia coli and Candida albicans of honey samples from five regions of the state of Paraná. Candida albicans yeast showed to be more resistant to honey than the bacteria Escherichia coli and Staphylococcus aureus. The minimal inhibitory concentration found for the three microorganisms tested was $12.5 \%$ to $25 \%$. The minimal bactericidal concentration, in its turn, was $25 \%$ for bacteria and $25 \%$ to $50 \%$ for yeast. The samples from the Southern area had the best results for both the minimal inhibitory and the bactericidal concentrations. Through physicochemical and phyto-chemical analysis, we observed that several factors are associated to the bactericidal capacity of honey. In conclusion, honey is an excellent bactericidal agent with a great biotechnological potential. Its properties are directly related to its geographic origin, which gives each type of honey its own characteristics.
\end{abstract}

Keywords: biotechnological potential; pathogenic microorganisms; healing properties of honey; phyto-chemical properties.

Practical Application: Evaluation of honey samples from different geographic regions of Paraná taking into account their antimicrobial activity and nutritional quality.

\section{Introduction}

Honey is an ancient option of food very appreciated by humanity as it is nutritious and easy to be digested. Moreover, it has numerous therapeutic applications, besides being an excellent food supplement (Pasupuleti et al., 2017). The Normative Instruction number 11/2000 from the Ministry of Agriculture, Livestock and Supply (MAPA) establishes the requisites of quality and identity of Apis mellifera honey and the acceptance criteria for the sensorial and technical production characteristics (Brasil, 2000).

Honey is considered the only natural product produced by insects to have nutritional, cosmetic, therapeutic and industrial values, mainly because its diverse beneficial properties have been scientifically proven (Ahmed et al., 2018). The antimicrobial activity of honey has drawn researchers' attention for its great applicability potential in clinical cases (Eteraf-Oskouei \& Najafi, 2013; Samarghandian et al., 2017).

Factors associated to the antibacterial capacity of honey are related especially to biocides of hydrogen peroxide, enzymatically produced in honey through the action of glucose oxidase, whose origin is the hypopharyngeal glands of bees (White et al., 1963). There are other compounds of honey that contribute in this process, such as its osmolarity, acidity, lysozyme, phenolic phyto-chemical compounds and flavonoids (Olaitan et al., 2007; Brudzynski et al., 2012; Ewnetu et al., 2013; Hegazi et al., 2017; Hussain, 2017; Bucekova et al., 2018). The honey is a natural product, can vary depending on factors such as processing, bee species, botanical origin, a period of the year, rainfall patterns and geographic location (Silva et al., 2016; Moraes et al., 2019; Aydogan-Coskun et al., 2019; Braga et al., 2020; Wabaidur et al., 2020; Yaqub et al., 2020). These factors directly interfere with the composition of pollen and nectar collected by bees (Al-Waili et al., 2011; Bucekova et al., 2018).

The presence of phenolic compounds helps avoiding diseases and retards ageing (Silva et al., 2016). According to Alvarez-Suarez et al. (2012), the main phenolic compounds found in honey are flavonoids. Some properties of flavonoids, such as the presence of hydroxyls in the aromatic rings, number and position of the hydroxyls and other substitutes, have a greater antioxidant capacity (Ben Sghaier et al., 2012; Silva et al., 2016).

The action of honey is vastly comprehensive, for it has a bactericidal and bacteriostatic function against gram-negative bacteria and gram-positive yeast and mold, not to mention 
its capacity to degrade bacterial genomic plasmids DNA (Brudzynski et al., 2012). There are studies on the antibacterial potential of honey for the treatment of wounds, respiratory infections and diarrhea, since it can combat more than sixty different pathogenic species of bacteria (Ewnetu et al., 2013; Hegazi et al., 2017; Hussain, 2017).

Therefore, considering the importance of honey for the treatment of diseases, this study aimed to analyze the bactericidal and bacteriostatic action of honey samples from different regions of the state of Paraná against the following pathogenic microorganisms, Staphylococcus aureus, Escherichia coli and Candida albicans, taking into account the phenolic composition and other phyto-chemical properties of the samples.

\section{Materials and methods}

\subsection{Honey sampling}

A total of 31 samples of the honey Apis mellifera, collected from August 2016 to February 2017, were analyzed. They were provided by beekeepers from six municipalities of five regions of Paraná, namely General Carneiro $(n=6)$; Pitanga $(n=6)$; Curitiba $(\mathrm{n}=6)$; Maringá $(\mathrm{n}=6)$; Marechal Cândido Rondon $(\mathrm{n}=4)$ and Santa Helena $(\mathrm{n}=3)$ (Figure 1).

\subsection{Preparation of the bacterial inoculums and standardization}

The microbiological analyses done with the honey samples included the pathogenic microorganisms Staphylococcus aureus ATCC 25923, Escherichia coli ATCC 25922 and Candida albicans ATCC 10231, in accordance with the Clinical and Laboratory Standards Institute (CLSI), document M07-A9 (2012) and M27 by A2 (Clinical and Laboratory Standards Institute, 2002) for yeast, with modifications by Sereia et al. (2017b), for all bacteria and yeast. All the analyses and their dilutions were done in triplicate.

\subsection{Antimicrobial Sensitivity Test - Broth Dilution Method}

We used 96-well microplates for the antimicrobial sensitivity test. For that, we added $1 \mathrm{~g}$ of honey to $1 \mathrm{~g}$ of Mueller Hinton (MH) broth for the bacteria and Sabouraud Dextrose (SD) broth for yeast. After homogenization, $200 \mu \mathrm{L}$ of this mixture were pipetted in the first well of every line of the plate. The other were completed with $100 \mu \mathrm{L}$ of the respective broth for each species, and three lines of the plate were used for each honey sample. A serial dilution was carried out in honey percentage according to the following proportions in each well: $1-50 \%, 2-25 \%$, $3-12.5 \%, 4-6.25 \%, 5-3.12 \%, 6-1.56 \%, 7-0.78 \%, 8-0.39 \%$,

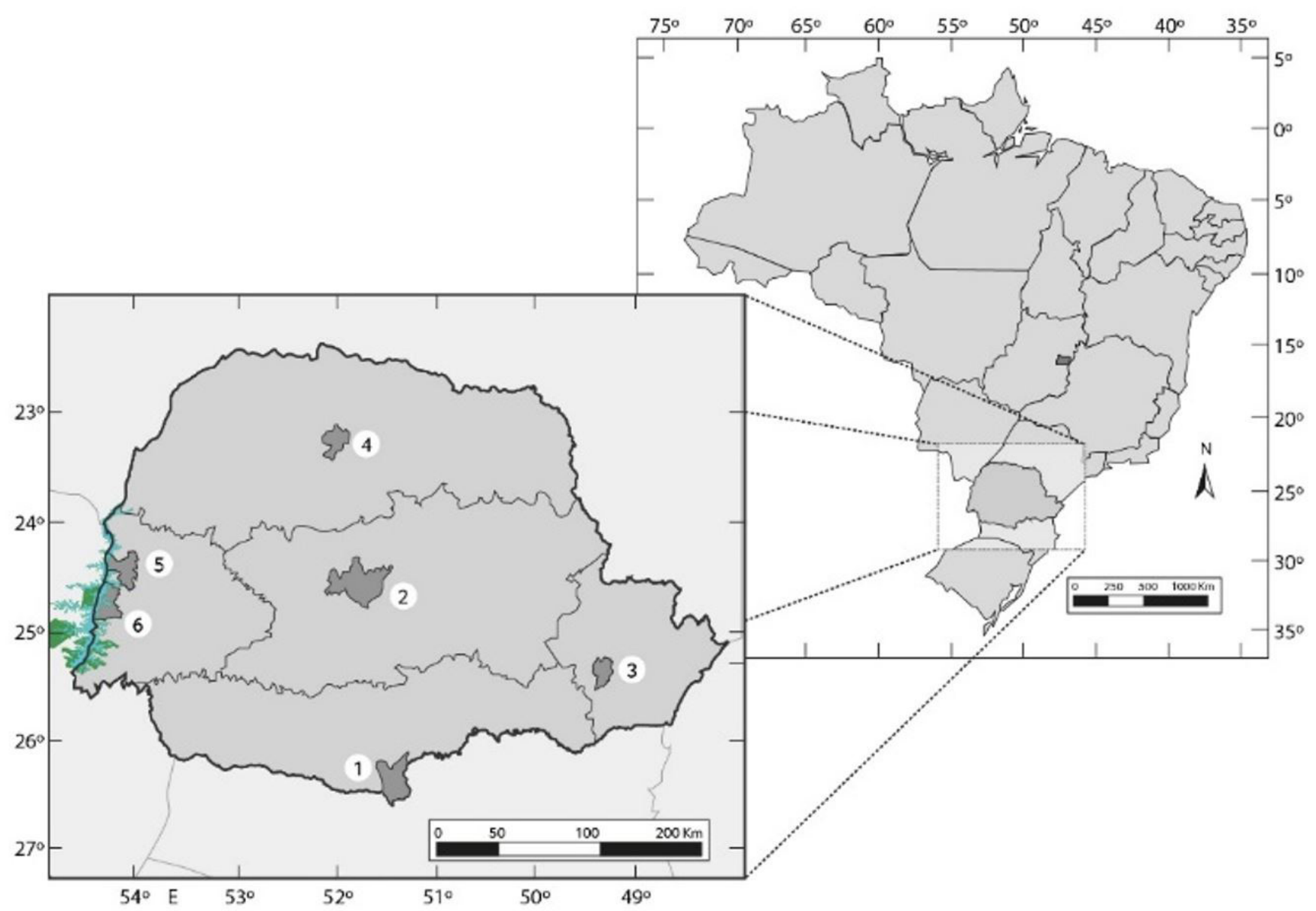

Figure 1. Location map of the areas covered by the study: (right) position of Paraná in Brazil; (left) the municipalities from where the samples were collected. 1 - General Carneiro; 2 - Pitanga; 3 - Curitiba; 4 - Maringá; 5 - Marechal Cândido Rondon and 6 - Santa Helena. 
$9-0.19 \%$, and 10 - bacterial control (without honey addition) and 11 - broth control (without honey and inoculums addition).

After honey addition, $5 \mu \mathrm{L}$ of the standardized suspension of the bacteria were inoculated in a way that the final concentration of bacteria per test was approximately $5 \times 10^{4} \mathrm{UFC} /$ well. The microplates were identified and incubated in a bacterial incubator at $35{ }^{\circ} \mathrm{C}$ for $24 \mathrm{~h}$. After the incubation period, the microplates were analyzed for determining the Minimal Inhibitory Concentration (MIC). The MIC was defined as the lowest concentration of honey in which there was no visible growth (turbidity) after incubation (Clinical and Laboratory Standards Institute, 2012; Sereia et al., 2017b). For determining the Minimal Bactericidal Concentration (MBC), we pipetted $10 \mu \mathrm{L}$ of the suspension of each well of the microplate that did not present growth and one subsequent well that presented turbidity in a Petri dish containing $\mathrm{MH}$ agar for E. coli and $S$. aureus, and SD agar for $C$. albicans yeast. The plates were identified e incubated in a bacterial incubator at $35^{\circ} \mathrm{C}$ for $24 \mathrm{~h}$, and analyzed for determining the MBC (Cruz et al., 2014).

\subsection{Physicochemical Analyses}

Moisture was determined through the refractometric method by using an Abbé refractometer (WY1Amodel). In order to determine the $\mathrm{pH}$, acidity and the formaldehyde index, we used a Marte pHmeter (MB10model) immersed in the sample, and a magnetic stirrer with heating (SL91 Solabmodel). For acidity and the formaldehyde index, the volumes in the respective titration were observed (Moraes \& Teixeira, 1998). As for ash content, the process was done in accordance with the method described by the Association of Official Analytical Chemists (2012) and with recommendations by Sereia et al. (2017a). The material was incinerated at $550^{\circ} \mathrm{C}$ in a muffle oven (Jung 0112 J200). Color was determined in accordance with Marchini et al. (2004), using a visible spectrophotometer (SP 2000model). The wavelength selected was $560 \mathrm{~nm}$, and Pfund was the colorimetric scale for comparing the result. For analyzing electric conductivity, we used a conductivimeter (HydroSanHy 150model). We weigh up $10 \mathrm{~g}$ of honey with an analytical scale and transferred them into a volumetric flask of $50 \mathrm{~mL}$ with distilled water. After that, reading was done (Association of Official Analytical Chemists, 2012). For the Hydroxymethylfurfural (HMF) analysis, the samples were analyzed in a visible spectrophotometer (SP 2000model) with wavelengths of $284 \mathrm{~nm}$ and $336 \mathrm{~nm}$ in quartz cuvettes (Association of Official Analytical Chemists, 2012). We used a nitrogen distiller (Micro Kjedahl Tecnal TE - 0363 model). Determination of total (\%) and reduced (\%) sugars and apparent sucrose (\%) was done based on AOAC recommendations (2012).

\subsection{Phyto-chemical analyses}

The Honey Extract was obtained by diluting honey in distilled water as a solvent $(4: 6, \mathrm{w} / \mathrm{v})$, to a solution with a honey concentration equal to 0.4 g.mL. Then, stir in the Vortex for a minute. This was followed by an ultrasonic bath for 15 minutes. Then, the extract was filtered through a qualitative paper filter to retain larger particles.
Quantification of the total phenols was done through the Folin-Ciocalteau method, adapted by Daves (2003) with recommendations by Sereia et al. (2017a). The standard curve with gallic acid was built at the concentrations of $0.00,0.03$, $0.018,0.033,0.060,0.090,0.120$, and $0.150 \mathrm{mg} \cdot \mathrm{mL}^{-1}$. The readings were done at the wavelength of $725 \mathrm{~nm}$. The results were expressed as $\mathrm{mg}$ of equivalent of gallic acid in $100 \mathrm{~g}$ of the sample (mg GAE/100 g ${ }^{-1}$ ).

The concentration of total flavonoids is determined through interpolation of the samples absorbance, based on a calibration curve built with quercetin standard (Association of Official Analytical Chemists, 2012; Sereia et al., 2017a). The standard curve was built with the following values: $0.000,0.020,0.027$, $0.031,0.048,0.055,0.090,0.0110$, and 0.237 . The results were expressed as mgEQ/100 $\mathrm{g}^{1}$ (Equivalent Quercetin).

Antioxidant activity was determined through the sequestrant capacity of the DPPH free radical (2,2 diphenyl-1-picryl-hydrazil) according to the method described by Roginsky \& Lissi (2005) with recommendations by Sereia et al. (2017a). For calculating $\mathrm{EC}_{50}$, we plotted a graph in triplicate in the abscissa (x axis) with the concentrations of 175.0, 350.0, 525.0, 700.0, and 875.0. The inhibition concentration of 0 to 100 for the $y$ axis. With the line equations, we calculated the values of $\mathrm{x}$ that correspond to the value of $\mathrm{EC}_{50^{\circ}}$.

\subsection{Statistical Analyses}

For interpreting the data, we used the average linkage method, which enables a multivariate analysis of the grouping, with the SAS Institute Inc. (1999), applying the Scott \& Knott (1974).

\section{Results and discussion}

\subsection{Antimicrobial Activity}

The three pathogenic organisms evaluated showed sensitivity to A. mellifera honey regardless of the region where it came from. The values found were $25 \%$ and $12.5 \%$ for the bacteriostatic test of Minimal Inhibitory Concentration (MIC). C. albicans yeast showed to be more sensitive than the bacteria E. colli and $S$. aureus, except in the samples from the Western region, in which $S$. aureus presented more sensitivity because the smaller the amount of honey necessary to hinder its growth, the better the functionality of honey (Table 1).

Similar results were found by Chan-Rodrigues et al. (2012), with inhibition from 15 to $31 \%$ for S. aureus and E. coli. Such results diverge from those found by Cruz et al. (2014), whose MIC was $7 \%$ for E. coli and S. aureus, and $40 \%$ for C. albicans, values that are considerably inferior compared to those of our experiment. Kuncic et al. (2012) analyzed Slovenian honey samples from several floral origins, which presented a MIC of $2.5 \%$ against S. aureus. As for C. albicans, there was no inhibition with any of the honey tested in the aforementioned experiment. The MIC for the bacteria was superior to what was found by us. However, regarding yeast, the honey did not have an efficient performance, which demonstrates that the samples from different regions of Paraná, and which we tested, have a positive effect against $C$. 
albicans yeast. As for the Minimal Bactericide Concentration (MBC), we observed that in all regions covered by this study, the results were similar to the MIC ones, except when it comes to $C$. albicans yeast, which showed more resistance compared to the bacteria. Osés et al. (2016) analyzed the bactericide activity of honey samples from different areas and the authors verified a MIC and an MBC of $10 \%$ for S. aureus, results that are superior to those of our study, in which the MIC values varied from $12.5 \%$ to $25 \%$, and $\mathrm{MBC}$ ones ranged from $25 \%$ to $50 \%$ among the different regions. These results may be related to regional origins, type of vegetation, blooming period and loss of antibacterial activity during processing and manipulation of honey (Irish et al., 2011). Just as the microorganisms used in our experiment, every microorganism has specific characteristics and behave differently in relation to honey. Yeast has a complex cell wall similar to that of the eukaryotes. Such characteristic protects it, avoiding the osmotic lysis of the protoplast and preventing toxic molecules from entering the cell wall to degrade it (Fukuda et al., 2009). These characteristics may have contributed to the significant difference between the MIC and the MBC in this experiment regarding C. albicans. The honey samples from the Southern region of Paraná showed better results for the MIC against the three microorganisms tested. That can be due to their content of phenols, flavonoids and antioxidant activity, respectively (Table 2 ).

\subsection{Bioactive compounds}

Phenolic compounds are produced by the secondary metabolism of plants, and they have a high antioxidant power.

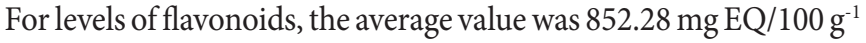

for south and up to $399.79 \mathrm{mg} \mathrm{EQ} / 100 \mathrm{~g}^{-1}$ for west (Table 2). These compounds show variation depending on the origin. However, the same behavior was detected in samples from the state of Rio Grande do Sul, ranging from 298.00 to $1046.00 \mathrm{mg} \mathrm{EQ} / 100 \mathrm{~g}^{-1}$ (Bueno-Costa et al., 2016).

Regarding the phenolic compounds, the samples from the Western region stood out for the lowest values, $143.67 \mathrm{mg} \mathrm{GAE} / 00 \mathrm{~g}^{-1}$ whereas the Southern region had the highest ones, $191.17 \mathrm{mg} \mathrm{GAE} / 100 \mathrm{~g}^{-1}$ (Table 2). These values present variation in relation to the single-flower honey samples from Rio Grande do Sul, which had values from 0.49 to $65.47 \mathrm{mg} \mathrm{GAE} / 100 \mathrm{~g}^{-1}$ (Bueno-Costa et al., 2016). The levels of phenolic compounds in honey samples can vary according to the botanical species (Wabaidur et al., 2020) and heat treatment applied (Aydogan-Coskun et al., 2019).

Since these compounds are transferred from plants to honey, each sample has a different profile, for the floral origin collected by the bees is different. That is why there are differences among regions, as well as environmental and seasonal factors (Kaškonienė \& Venskutonis, 2010).

The antioxidant activity of the samples from the Southern area had an $\mathrm{EC}_{50}$ of $1.94 \mu \mathrm{g} \cdot \mathrm{mL}^{-1}$, which was superior to the activity of the samples from the Western region, with $3.02 \mu \mathrm{g} \cdot \mathrm{mL}^{-1}$. That may be related to the sample colors, as the ones from the South area were predominantly light amber. According to Ferreira et al. (2009), the antioxidant variation can vary depending on the color of the samples evaluated. Linda et al. (2012) analyzed samples of wild honey from different municipalities of Rio de Janeiro and found an $\mathrm{EC}_{50}$ from 8.17 to $51.45 \mu \mathrm{g} \cdot \mathrm{mL}^{-1}$. This demonstrates

Table 1. Bacteriostatic test of Minimal Inhibitory Concentration (MIC) and bactericide test of the Minimal Bactericide Concentration (MBC) of 31 Apis mellifera honey samples, collected from different regions of the state of Paraná, against Escherichia coli, Staphylococcus aureus and Candida albicans.

\begin{tabular}{|c|c|c|c|c|c|c|c|}
\hline \multirow[b]{2}{*}{ Regions } & \multirow[b]{2}{*}{ No samples } & \multicolumn{3}{|c|}{ MIC \% } & \multicolumn{3}{|c|}{ MBC \% } \\
\hline & & Escherichia coli & $\begin{array}{c}\text { Staphylococcus } \\
\text { aureus }\end{array}$ & $\begin{array}{l}\text { Candida } \\
\text { albicans }\end{array}$ & Escherichia coli & $\begin{array}{c}\text { Staphylococcus } \\
\text { aureus }\end{array}$ & $\begin{array}{l}\text { Candida } \\
\text { albicans }\end{array}$ \\
\hline South & 6 & 25 & 25 & 12.5 & 25 & 25 & 25 \\
\hline Central & 6 & 25 & 25 & 12.5 & 25 & 25 & 50 \\
\hline East & 6 & 25 & 25 & 12.5 & 25 & 50 & 50 \\
\hline Northwest & 6 & 25 & 25 & 25 & 25 & 50 & 50 \\
\hline Western & 7 & 25 & 12.5 & 25 & 25 & 25 & 50 \\
\hline
\end{tabular}

Table 2. Flavonoid levels, total phenols, antioxidant activity and color of the samples of Apis mellifera honey from different regions of the state of Paraná, Brazil.

\begin{tabular}{lccccc}
\hline \multicolumn{1}{c}{ Regions } & $\begin{array}{c}\mathrm{N}^{\mathrm{c}} \\
\text { samples }\end{array}$ & $\begin{array}{c}\text { Total flavonoid } \\
\left(\mathrm{mg} \mathrm{EQ} / 100 \mathrm{~g} \mathrm{~g}^{-1}\right)\end{array}$ & $\begin{array}{c}\text { Total phenol } \\
\left(\mathrm{mg} \mathrm{GAE} / 100 \mathrm{~g} \mathrm{~g}^{-1}\right)\end{array}$ & $\begin{array}{c}\text { Antioxidant activities EC } \\
50\left(\mu \mathrm{g} \cdot \mathrm{mL}^{-1}\right)\end{array}$ & Color \\
\hline South & 6 & $852.28 \pm 3.71^{\mathrm{b}}$ & $191.17 \pm 1.91^{\mathrm{c}}$ & $1.94 \pm 0.072^{\mathrm{a}^{*}}$ & Amber \\
Central & 6 & $515.97 \pm 5.86^{\mathrm{a}}$ & $174.22 \pm 10.43^{\mathrm{b}}$ & $2.79 \pm 0.051^{\mathrm{b}}$ & Light amber \\
East & 6 & $764.68 \pm 4.54^{\mathrm{b}}$ & $185.33 \pm 8.66^{\mathrm{c}}$ & $2.64 \pm 0.118^{\mathrm{b}}$ & Amber \\
Northwest & 6 & $508.13 \pm 3.44^{\mathrm{a}}$ & $187.00 \pm 5.77^{\mathrm{c}}$ & $2.88 \pm 0.044^{\mathrm{b}}$ & Light amber \\
Western & 7 & $399.79 \pm 6.19^{\mathrm{a}}$ & $143.67 \pm 5.00^{\mathrm{a}}$ & $3.02 \pm 0.043^{\mathrm{b}}$ & Light amber \\
\hline
\end{tabular}

Results expressed as mean and standard deviation. Lower case letters do not differ statistically in the column $(\mathrm{p}<0.05)$. 
that variation is common among different samples, and that the honey evaluated presents antioxidant activity.

The antioxidant activity of honey may be related to flavonoids such as quercetin, flavones, isoflavones, flavonones, anthocyanins, catechins and isocatechins, and the phenolics may participate together with the flavonoids in determining the antioxidant activities (Silva et al., 2006). That factor may have had influence on the positive MIC and MBC results.

Another important factor that must be analyzed is honey color. Taormina et al. (2001) report that honey samples of darker colors reflect, in parts, the content of pigments such as carotenoids and flavonoids, thus having greater inhibition capacity compared to honey of light colors. Evaluation of samples from 14 municipalities in Western Paraná, presented values similar to those observed in this study, this low content of total flavonoid and total phenol. It may be due to the high percentage of samples of light shades of honey produced in the region, where the authors observed $67.16 \%$ of the samples presented light amber color (Galhardo et al., 2020). This characteristic of honey from the Western region is associated with a botanical origin that has a dominance of Hovenia dulcis (Moraes et al., 2019) which presents lighter shades of honey (Nascimento et al., 2018).

Most of the samples from South and East showed amber color and also the highest values of antioxidant activity. Bueno-Costa et al. (2016) identified a small variation in colors of samples from Rio Grande do Sul, with predominance of dark colors. Moreti et al. (2006) found out that light amber was predominant in $44.5 \%$ of 346 samples from six Brazilian states (Bahia, Tocantins, Piauí, Ceará, Minas Gerais and Santa Catarina). The authors also state that the variation in shade of Brazilian honey is probably due to its floral origin. In Brazil, there is a wide variety of vegetation, with several types of crops.

Nonetheless, despite having results that were inferior to those from the southern area when it comes to phyto-chemical properties and light colors, the West region achieved interesting
MIC and MBC results. Thus, it shows that other compounds are directly related to antimicrobial capacity, such as the action of the hydrogen peroxide created during glucose oxidation by the glucose-oxidase enzyme, as well as the osmotic effect of honey, which dehydrates pathogenic microorganisms through high sugar levels (Carnwath et al., 2014; McLoone et al., 2016; Hussain, 2017).

\subsection{Physicochemical parameters}

The results regarding physicochemical properties of the samples from all regions met the standards established by the Normative Ruling number 11/2000 (Brasil, 2000). Moisture values ranged from $17.78 \%$ for samples from northwest and $18.51 \%$ those from west $(\mathrm{p}<0.05)$. The $\mathrm{pH}$ value varied from maximum 4.79 for the samples from the southern area to minimum 3.98 for those from the west region $(\mathrm{p}<0.05)$. With regard to reducing sugars, total reducing sugars and sucrose of the samples, south and west had a different performance compared to other regions, with the highest values $(\mathrm{p}<0.05)$ (Table 3$)$.

The fact that all values met the requirements of the national regulations for bee products shows that all samples analyzed are in accordance with marketing standards. Similar results were found in a comparative analysis by Habib et al. (2014). The authors analyzed the physicochemical properties of 11 honey samples from Arid regions and 5 from Non-Arid regions, and found similar values, with $\mathrm{pH}$ around 4.76 , moisture at $17.32 \%$ and $80.95 \%$ for sugar.

The values obtained for physicochemical properties contribute to understanding the results achieved in our experiment for both the MIC and MBC regarding the West. This region had the lowest values when it comes to phyto-chemical compounds (Table 2). However, it showed low $\mathrm{pH}$, a low moisture index and high levels of sugar. All these combined result in excellent bactericidal action. Gethin et al. (2008), when analyzing interference of the $\mathrm{pH}$ with topical treatment of wounds with honey, concluded that a reduction of 0.1 unit of $\mathrm{pH}$ could be associated to a reduction of $8.1 \%$ in the size of wounds.

Table 3. Mean and standard deviation of the values for physicochemical characteristics of the Apis mellifera honey samples from different regions of Paraná, Brazil.

\begin{tabular}{|c|c|c|c|c|c|}
\hline Parameters & South $(n=6)$ & Central $(n=6)$ & East $(\mathrm{n}=6)$ & Northwest $(n=6)$ & Western $(\mathrm{n}=7)$ \\
\hline Moisture (\%) & $18.24 \pm 0.19^{b}$ & $17.84 \pm 0.35^{\mathrm{a}}$ & $18.38 \pm 0.19^{b}$ & $17.78 \pm 0.33^{a}$ & $18.51 \pm 0.21^{b}$ \\
\hline $\mathrm{pH}$ & $4.79 \pm 0.12^{c}$ & $4.17 \pm 0.03^{a}$ & $4.42 \pm 0.03^{b}$ & $4.31 \pm 0.05^{b}$ & $3.98 \pm 0.05^{\mathrm{a}}$ \\
\hline Reducing sugar (\%) & $74.39 \pm 1.23^{b}$ & $71.72 \pm 0.46^{\mathrm{a}}$ & $70.49 \pm 0.72^{a}$ & $72.00 \pm 0.91^{\mathrm{a}}$ & $74.26 \pm 0.37^{b}$ \\
\hline Total Sugar (\%) & $78.95 \pm 0.18^{b}$ & $74.31 \pm 0.75^{a}$ & $73.29 \pm 0.95^{\mathrm{a}}$ & $74.31 \pm 0.68^{a}$ & $79.05 \pm 0.17^{b}$ \\
\hline Sucrose (\%) & $4.43 \pm 1.84^{b}$ & $2.52 \pm 0.45^{\mathrm{a}}$ & $2.71 \pm 1.16^{\mathrm{a}}$ & $2.25 \pm 1.26^{\mathrm{a}}$ & $4.6 \pm 0.51^{b}$ \\
\hline Total acidity (mEq. $\left.\mathrm{kg}^{-1}\right)$ & $24.98 \pm 1.05^{\mathrm{a}}$ & $26.52 \pm 1.13^{a}$ & $27.61 \pm 0.84^{\mathrm{a}}$ & $32.08 \pm 1.12^{b}$ & $34.69 \pm 0.63^{c}$ \\
\hline Formaldehyde (mL. $\left.\mathrm{Kg}^{-1}\right)$ & $22.15 \pm 1.39^{b}$ & $20.86 \pm 0.42^{b}$ & $20.16 \pm 0.42^{b}$ & $18.08 \pm 1.84^{b}$ & $13.17 \pm 1.33^{\mathrm{a}}$ \\
\hline Ahs (\%) & $0.35 \pm 0.05^{b}$ & $0.38 \pm 0.21^{b}$ & $0.22 \pm 0.04^{\mathrm{a}}$ & $0.21 \pm 0.07^{\mathrm{a}}$ & $0.15 \pm 0.04^{\mathrm{a}}$ \\
\hline Conductivity $\left(\mu \mathrm{S} . \mathrm{cm}^{-1}\right)$ & $714.3 \pm 14.73^{c}$ & $391.1 \pm 18.63^{b}$ & $482.7 \pm 29.37^{b}$ & $470.5 \pm 23.52^{b}$ & $269.8 \pm 12.58^{a}$ \\
\hline $\mathrm{HMF}\left(\mathrm{mg} . \mathrm{Kg}^{-1}\right)$ & $3.81 \pm 0.10^{\mathrm{a}}$ & $4.33 \pm 0.11^{a}$ & $3.79 \pm 0.21^{\mathrm{a}}$ & $3.38 \pm 0.21^{\mathrm{a}}$ & $3.81 \pm 0.18^{a}$ \\
\hline Protein (\%) & $0.372 \pm 0.0^{\mathrm{b}}$ & $0.208 \pm 0.02^{\mathrm{a}}$ & $0.192 \pm 0.06^{\mathrm{a}}$ & $0.402 \pm 0.12^{b}$ & $0.344 \pm 0.03^{b}$ \\
\hline Solids soluble & $81.76 \pm 0.19^{b}$ & $82.16 \pm 0.35^{\mathrm{a}}$ & $81.62 \pm 0.19^{b}$ & $82.62 \pm 0.33^{a}$ & $81.49 \pm 0.21^{b}$ \\
\hline
\end{tabular}

$\mathrm{pH}=$ Hydrogen potential; HMF = 5-hydroxymethylfurfural. ${ }^{a}$ Brasil (2000). Lower case letters show statistical differences in the same line $(\mathrm{p}<0.05)$ 
Regarding the analyses of total acidity, formaldehyde, ash content and electrical conductivity, the highest values found were those from the South. However, the West area had the lowest ones, which means a statistical difference of $(\mathrm{p}<0.05)$. As for the protein index, the lowest value $(0.19 \%)$ was found in the samples from East, and the highest one $(0.40 \%)$ for Northwest $(\mathrm{p}<0.05)$. In terms of soluble solids, the Central and Northwest areas presented higher values in comparison to the other $(\mathrm{p}<0.05)$. Yet, all samples were in compliance with the Brazilian Normative Ruling number 11/2000 (Brasil, 2000).

Honey acidity can be considered an important factor for its antimicrobial activity, since the acids dissolved in aqueous solution and the presence of inorganic ions such as phosphate and chlorides hinder the fermentation process and contribute to preserving it (Andrade et al., 1999). Acidity of the samples from West had the highest values $\left(34.69 \mathrm{mEq} \cdot \mathrm{kg}^{-1}\right)$, which gives honey great bactericidal and bacteriostatic power. With regard to proteins, the values depend on blooming enzymes produced by the bees themselves and derivatives of nectar. There are no limit protein values prescribed by Brazilian regulations. Therefore, the values detected are in accordance with the standards. The HMF of the samples from all the five regions did not show variation. That can be explained by the fact that the samples had been recently collected. Besides, they did not undergo processing or heating. The maximum value according to the legislation is 60 , and all samples had results lower than 4.5 .

These results attest conformity with what is required by the legislation on the marketing of $A$. mellifera honey. They all indicate that the physicochemical, as well as the phyto-chemical characteristics were preserved, with no sign of adulteration. Such results reinforce those referring to the antimicrobial action of the honey samples analyzed in this study.

\section{Conclusions}

The results found for the MIC and MBC show that there are differences among the honey samples collected. Bactericidal and bacteriostatic action had a more considerable difference regarding C. albicans yeast, which showed to be more resistant than the bacteria. The phyto-chemical parameters analyzed had differences among the regions, which shows that the area has influence over honey composition, and that the physicochemical properties also influence the antimicrobial action of honey. Therefore, honey can be considered a bactericidal and bacteriostatic agent, with a high biotechnological potential.

\section{Acknowledgements}

We thank the National Council for Scientific and Technological Development $(\mathrm{CNPq})$ for financing our project (Process No. 311072/2019-4).

\section{References}

Ahmed, S., Sulaiman, S. A., Baig, A. A., Ibrahim, M., Liaqat, S., Fatima, S., Jabeen, S., Shamim, N., \& Othman, N. H. (2018). Honey as a potential natural antioxidant medicine: an insight into its molecular mechanisms of action. Oxidative Medicine and Cellular Longevity, 2018(8367846), 1-19. http://dx.doi.org/10.1155/2018/8367846. PMid:29492183.
Alvarez-Suarez, J. M., Giampieri, F., Gonzalez-Paramas, A. M., Damiani, E., Astolfi, P., Martinez-Sanchez, G., Bompadre, S., Quiles, J. L., Santos-Buelga, C., \& Battino, M. (2012). Phenolics from monofloral honeys protect human erythrocyte membranes against oxidative damage. Food and Chemical Toxicology, 50(5), 1508-1516. http://dx.doi.org/10.1016/j.fct.2012.01.042. PMid:22330201.

Al-waili, N. S., Salom, K., Butler, G., \& Al-Ghamdi, A. A. (2011). Honey and microbial infections: a review supporting the use of honey for microbial control. Journal of Medicinal Food, 14(10), 1079-1096. http://dx.doi.org/10.1089/jmf.2010.0161. PMid:21859350.

Andrade, P. B., Amaral, M. T., Isabel, P., Carvalho, J. C. M. F., Seabra, R. M., \& Cunha, A. P. C. (1999). Physicochemical attributes and pollen spectrum of Portuguese heather honeys. Food Chemistry, 66(4), 503-510. http://dx.doi.org/10.1016/S0308-8146(99)00100-4.

Association of Official Analytical Chemists - AOAC. (2012). Official methods of analysis of the Association of Official Analytical Chemists. Arlington: AOAC.

Aydogan-Coskun, B., Coklar, H., \& Akbulut, M. (2019). Effect of heat treatment for liquefaction and pasteurization on antioxidant activity and phenolic compounds of Astragalus and sunflower-cornflower honeys. Food Science and Technology, 39, 1-6.; Epub. http://dx.doi. org/10.1590/fst.15519.

Ben Sghaier, M., Skandrani, I., Nasr, N., Franca, M.-G. D., ChekirGhedira, L., \& Ghedira, K. (2012). Flavonoids and sesquiterpenes from Tecurium ramosissimum promote antiproliferation of human cancer cells and enhance antioxidant activity: A structure-activity relationship study. Environmental Toxicology and Pharmacology, 32(3), 336-348. http://dx.doi.org/10.1016/j.etap.2011.07.003. PMid:22004952.

Braga, D. C., Liberato, M. D. C. T. C., Lima, V. L. F., \& Araújo Neto, J. A. M. D. (2020). Analytical study of the physicochemical characteristics from Melipona subnitida D. honey in adequation to Brazilian law. Food Science and Technology, 40(suppl 1), 217-221. http://dx.doi. org/10.1590/fst.08919.

Brasil. Ministério da Agricultura, Pecuária e Abastecimento (2000, Outubro 20) Instrução Normativa no 11 , de 20 de outubro de 2000. Regulamento técnico de identidade e qualidade do mel. Diário Oficial [da] República Federativa do Brasil. Retrieved from http:// www.agricultura.gov.br/sda/dipoa/in_11_2000.htm.

Brudzynski, K., Abubaker, K., \& Miotto, K. (2012). Unraveling a mechanism of honey antibacterial action: Polyphenol/H2O2-induced oxidative effect on bacterial cell growth and on DNA degradation. Food Chemistry, 133(2), 329-336. http://dx.doi.org/10.1016/j. foodchem.2012.01.035. PMid:25683403.

Bucekova, M., Juricova, V., Monton, E., Martinotti, S., Ranzato, E., \& Majtan, J. (2018). Microwave processing of honey negatively affects honey antibacterial activity by inactivation of beederived glucose oxidase and defensin-1. Food Chemistry, 240, 1131-1136. http://dx.doi.org/10.1016/j.foodchem.2017.08.054. PMid:28946234.

Bueno-Costa, F. M., Zambiazi, R. C., Bohmer, B. W., Chaver, F. C., Silva, W. P., Zanusso, J. T., \& Dutra, I. (2016). Antibacterial and antioxidant activity of honeys from the state of Rio Grande do Sul, Brazil. Food Science and Technology, 65, 333-340. http://dx.doi. org/10.1016/j.lwt.2015.08.018.

Carnwath, R., Graham, E. M., Reynolds, K., \& Pollock, P. J. (2014). The antimicrobial activity of honey against the common isolates of equine wound bacteria. Veterinary Journal, 199(1), 110-114. http:// dx.doi.org/10.1016/j.tvjl.2013.07.003. PMid:23962613. 
Chan-Rodrigues, D., Ramón-Sierra, J., Lope-Ayora, J., Sauri-Duch, E., Cuevas-Glory, L., \& Ortiz-Vázquez, E. (2012). Antibacterial properties of honey produced by Melipona beecheii and Apis mellifera against foodborn microorganisms. Food Science and Biotechnology, 21(3), 905-909. http://dx.doi.org/10.1007/s10068-012-0118-x.

Clinical and Laboratory Standards Institute - CLSI. (2002). Norma M27-A2: Método de referência para testes de diluição em caldo para determinação da sensibilidade de leveduras à terapia antifúngica (2a ed., p. 51). Pennsylvania: NCCLS.

Clinical and Laboratory Standards Institute - CLSI. (2012). Performance standards for antimicrobial disk susceptibility test; Approved standand - Twelfth Edition. Wayne: CLSI.

Cruz, A. B. N., Pieri, F. A., Zilse-Carvalho, G. A., Orlandi, P. P., NunesSilva, C. G., \& Leonil, L. (2014). Antimicrobial activity of honeys from two stingless honeybee species and Apis mellifera (Hymenoptera: Apidae) against pathogenic microorganisms. Acta Amazonica, 44(2), 1-4. http://dx.doi.org/10.1590/S0044-59672014000200015.

Daves, J. W. (2003). Current protocols in food analytical chemistry (pp. 1073-1080). California: John Wiley \& Sons.

Eteraf-Oskouei, T., \& Najafi, M. (2013). Traditional and modern uses of natural honey in human diseases: a review. Iranian Journal of Basic Medical Sciences., 16(6), 731-742. PMid:23997898.

Ewnetu, Y., Lemma, W., \& Birhane, N. (2013). Antibacterial effects of Apis mellifera and stingless bees honeys on susceptible and resistant strains of Escherichia coli, Staphylococcus aureus and Klebsiella pneumoniae in Gondar, Northwest Ethiopia. BMC Complementary and Alternative Medicine, 13(269), 1-7. http://dx.doi.org/10.1186/14726882-13-269. PMid:24138782.

Ferreira, I. C., Aires, E., Barreira, J. C., \& Estevinho, L. M. (2009). Antioxidant activity of Portuguese honey samples: Different contributions of the entire honey and phenolic extract. Food Chemistry, 114(4), 14381443. http://dx.doi.org/10.1016/j.foodchem.2008.11.028.

Fukuda, E. K., Vasconcelos, A. F. D., Matias, A. C., Barbosa, A. M., Dekker, R. F. H., \& Silva, M. L. C. (2009). Fungal cell wall polysaccharides: purification and characterization. Semina: Ciências Agrárias, 30(1), 17-134. http://dx.doi.org/10.5433/1679-0359.2009v30n1p117.

Galhardo, D., Garcia, R. C., Schneider, C. R., Braga, G. B., Chambó, E. D., França, D. L. B \& Ströher, S. M. (2020). Physicochemical, bioactive properties and antioxidant of Apis mellifera L. honey from western Paraná, Southern Brazil. Food Science and Technology, 40, 1-7. https://doi.org/10.1590/fst.11720

Gethin, G. T., Cowman, S., \& Conroy, R. M. (2008). The impact of Manuka honey dressings on the surface $\mathrm{pH}$ of chronic wounds. International Wound Journal, 5(2), 185-194. http://dx.doi.org/10.1111/j.1742481X.2007.00424.x. PMid:18494624.

Habib, H. M., Al Meqbali, F. T., Kamal, H., Souka, U., \& Ibrahim, W. H. (2014). Physical-chemical and biochemical properties of honeys from arid regions. Food Chemistry, 153, 35-43. http://dx.doi.org/10.1016/j. foodchem.2013.12.048. PMid:24491697.

Hegazi, A. G., Al Guthami, F. M., Al Gethami, A. F., Allah, F. M., Saleh, A. A., \& Fouad, E. A. (2017). Potential antibacterial activity of some Saudi Arabia honey. Veterinary World, 10(2), 233-237. http://dx.doi. org/10.14202/vetworld.2017.233-237. PMid:28344408.

Hussain, M. B. (2017). Role of honey in topical and systemic bacterial infections. Journal of Alternative and Complementary Medicine, 24(1), 1-10. http://dx.doi.org/10.1089/acm.2017.0017. PMid:28837361.

Irish, I., Blair, S., \& Carter, D. A. (2011). The antibacterial activity of honey derived from Australian flora. PLoS One, 6(3), e18229. http://dx.doi.org/10.1371/journal.pone.0018229. PMid:21464891.
Kaškonienė, V., \& Venskutonis, P. R. (2010). Floral markers in honey of various botanical and geographic origins: a review. Comprehensive Reviews in Food Science and Food Safety, 9(6), 620-634. http://dx.doi. org/10.1111/j.1541-4337.2010.00130.x.

Kuncic, M. K., Jaklic, D., Lapanje, A., \& Gunde-Cimerman, N. (2012). Antibacterial and antimycotic activities of Slovenian honeys. British Journal of Biomedical Science, 69(4), 154-158. http://dx.doi.org/10 .1080/09674845.2012.12069144. PMid:23304790.

Linda, R. P. P., Sant'Ana, L. O., Echevarria, A., \& Castro, R. N. (2012). Antioxidant activity and phenolic composition of Brazilian honeys and their extracts. Journal of the Brazilian Chemical Society, 23(4), 618-627. http://dx.doi.org/10.1590/S0103-50532012000400006.

Marchini, L. C., \& Sodré, G. S. \& Moreti, A. C. C. C. (2004). Mel brasileiro, composição e normas. Ribeirão Preto: ASP.

McLoone, P., Warnock, M., \& Fyfe, L (2016). Honey: a realistic antimicrobial for skin disorders. Journal of Microbiology, Immunology, and Infection, 49(2), 161-167. http://dx.doi.org/10.1016/j.jmii.2015.01.009. PMid:25732699.

Moraes, F. J., Garcia, R. C., Galhardo, D., Camargo, S. C., Pires, B. G., Pereira, D. J., \& de Sousa, P. H. A. A. (2019). Pollen analysis of honey samples produced in the counties of Santa Helena and Terra Roxa, western Region of Paraná, Southern Brazil. Sociobiology, 66(2), 327338. http://dx.doi.org/10.13102/sociobiology.v66i2.3680.

Moraes, R. M., \& Teixeira, E. W. (1998). Análises de mel (manual técnico) (pp. 1-42). Pindamonhangaba: SAA/AMA.

Moreti, A. C. C. C., Sodré, G. S., \& Marchini, L. C. (2006). Cor de amostras de mel de Apis mellifera L. de diferentes estados brasileiros. Boletim de Indústria Animal, 63(3), 159-164.

Nascimento, K. S., Gasparotto Sattler, J. A., Lauer Macedo, L. F., Serna González, C. V., Pereira de Melo, I. L., Silva Araújo, E., Granato, D., Sattler, A., \& Almeida-Muradian, L. B (2018). Phenolic compounds, antioxidant capacity and physicochemical properties of Brazilian Apis mellifera honeys. Lebensmittel-Wissenschaft + Technologie, 91, 85-94. http://dx.doi.org/10.1016/j.lwt.2018.01.016.

Olaitan, P. B., Adeleke, O. E., \& Ola, I. O. (2007). Honey: a reservoir for microorganisms and an inhibitory agent for microbes. African Health Sciences, 7(3), 159-165. http://dx.doi.org/10.5555/afhs.2007.7.3.159. PMid:18052870.

Osés, S. M., Pascual-Maté, A., Fernàndez-Muiño, M. A., Lópes-Díaz, T. M., \& Sancho, M. T. (2016). Bioactive properties of honey with propolis. Food Chemistry, 196, 1215-1223. http://dx.doi.org/10.1016/j. foodchem.2015.10.050. PMid:26593609.

Pasupuleti, V. R., Sammugam, L., Ramesh, N., \& Gan, S. H. (2017). Honey, propolis, and royal jelly: a comprehensive review of their biological actions and health benefits. Oxidative Medicine and Cellular Longevity, 2017, 1-21. http://dx.doi.org/10.1155/2017/1259510. PMid:28814983.

Roginsky, V., \& Lissi, E. A. (2005). Review of methods to determine chain-breaking antioxidant activity in food. Food Chemistry, 92(2), 235-254. http://dx.doi.org/10.1016/j.foodchem.2004.08.004.

Samarghandian, S., Farkhondeh, T., \& Samini, F. (2017). Honey and health: a review of recent clinical research. Pharmacognosy Research, 9(2), 121-127. http://dx.doi.org/10.4103/0974-8490.204647. PMid:28539734.

SAS Institute Inc. (1999). SAS/STAT User's Guide, Version 8 (vol. 2). Cary, NC: SAS Institute, Inc.

Scott, A. J., \& Knott, M. (1974). A cluster analysis method for grouping means in the analysis of variance. Biometrics, 30(3), 507-512. http:// dx.doi.org/10.2307/2529204. 
Sereia, M. J., Março, P. H., Perdoncini, M. R. G., Parpinelli, R. S., Lima, E. G., \& Anjo, F. A. (2017a). Techniques for the evaluation of physicochemical quality and bioactive compounds in honey. In V. A. A. Toledo (Ed.), Honey Analysis (pp. 193-214). London, UK: InTech Open. http://dx.doi.org/10.5772/66839

Sereia, M. J., Perdoncini, M. R. G., Março, P. H., Parpinelli, R. S., Lima, E. G., \& Anjo, F. A. (2017b). Techniques for the evaluation of microbiological quality in honey. In V. A. A. Toledo (Ed.), Honey Analysis (p. 193-214). London, UK: InTech Open. http://dx.doi. org/10.5772/67086

Silva, J. F. M., Souza, M. C., Matta, S. R., Andrade, M. R., \& Vidal, F. V. N. (2006). Correlation analysis between phenolic levels of Brazilian propolis extracts and their antimicrobial and antioxidant activities. Food Chemistry, 99(3), 431-435. http://dx.doi.org/10.1016/j. foodchem.2005.07.055.

Silva, P. M., Gauche, C., Gonzaga, L. V., Costa, A. C. O., \& Fett, R. (2016). Honey: Chemical composition, stability and authenticity. Food Chemistry, 196, 309-323. http://dx.doi.org/10.1016/j. foodchem.2015.09.051. PMid:26593496.

Taormina, P. J., Niemira, B. A., \& Beuchat, L. R. (2001). Inhibitory activity of honey against foodborne pathogens as influenced by the presence of hydrogen peroxide and level of antioxidant power. International Journal of Food Microbiology, 69(3), 217-225. http://dx.doi.org/10.1016/S0168-1605(01)00505-0. PMid:11603859.

Wabaidur, S. M., Obbed, M. S., Alothman, Z. A., Alfaris, N. A., Badjah-Hadj-Ahmed, A. Y., Siddiqui, M. R., Altamimi, J. Z., \& Aldayel, T. S. (2020). Total phenolic acids and flavonoid contents determination in Yemeni honey of various floral sources: Folin-Ciocalteu and spectrophotometric approach. Food Science and Technology, Ahead of Print. http://dx.doi.org/10.1590/fst.33119.

White, J. W. Jr, Subers, M. H., \& Schepartz, A. I. (1963). The identification of inhibine, the antibacterial factor in honey, as hydrogen peroxide and its origin in a honey glucose-oxidase system. Biochimica et Biophysica Acta (BBA)-Specialized Section on Enzymological Subjects, 73(1), 57-70. http://dx.doi.org/10.1016/0006-3002(63)90359-7. PMid:14000328.

Yaqub, G., Khalid, M., Ikram, A., \& Sohail, A. (2020). Monitoring and risk assessment due to presence of metals and pesticides residues in honey samples from the major honey producing forest belts and different brands. Food Science and Technology, 40(Suppl. 1), 331-335. https://doi.org/10.1590/fst.01919. 